\title{
Nutritive Value of Alfalfa Harvested with a Modified Flail Chopper
}

\author{
Jadwiga Andrzejewska ${ }^{1, *}$, Stanisław Ignaczak $^{1}$ and Kenneth A. Albrecht ${ }^{2}$ (D) \\ 1 Department of Agronomy, University of Science and Technology, 85-796 Bydgoszcz, Poland; \\ signac@utp.edu.pl \\ 2 Department of Agronomy, University of Wisconsin-Madison, Madison, WI 53706, USA; kaalbrec@wisc.edu \\ * Correspondence: jadwiga.andrzejewska@utp.edu.pl
}

Received: 16 April 2020; Accepted: 8 May 2020; Published: 13 May 2020

\begin{abstract}
The leaves of alfalfa (Medicago sativa L.) are a valuable source of protein, and the stems a source of fiber. Harvest methods are sought that would allow separation of different plant fractions for agricultural or industrial functions. A solution is proposed, consisting of collecting leaves together with upper, fine stem fragments, while leaving most of the stem standing in the field. For this purpose, a modified flail chopper (MFC), typically used for harvesting green forage, was employed. The objective of this study was to assess the forage value of alfalfa biomass harvested at various development stages using an MFC, and stem stubble remaining after harvest. Alfalfa was harvested with a sickle-bar mower or MFC in the first and second cuts at bud, early flower and late flower stages of development. Using the MFC, $60 \%$ to $74 \%$ of the potential dry matter yield of alfalfa was harvested, in which the proportion of leaves was, on average, $22 \%$ greater than the proportion of leaves in forage harvested with a mower. Crude protein concentration was, on average, $16 \%$ greater and neutral detergent fiber concentration 13\% less in alfalfa harvested with the MFC than with a mower. In alfalfa harvested with the MFC at early flower, crude protein concentration and in vitro true digestibility were similar or greater than, with neutral and acid detergent fiber at a similar or lower level as in forage harvested with a mower at bud stage. The forage nutritive value of alfalfa harvested with an MFC at late flower was similar to the forage value of alfalfa cut with a mower at early flower. The chemical composition of the 20 to $50 \mathrm{~cm}$ tall residual stubble was affected little by plant maturity or harvest method, and the quality parameters also indicate the possibility of its forage use.
\end{abstract}

Keywords: Medicago sativa; flail chopper; leaf harvest; forage nutritive value

\section{Introduction}

In the European Union, and especially in the countries of Central Europe, a shortage of protein for livestock rations has been of concern for many years [1]. The relatively cool and short growing season, and increasingly frequent periods of drought, makes cultivation of home-grown seed legumes unprofitable, which results in dependence on the import of soybean meal [2]. On the other hand, the attributes of perennial legumes, especially alfalfa (Medicago sativa L.), remain undervalued and underutilized. Of the commonly grown forage crops, alfalfa has the greatest potential for the production of feed with a high concentration and yield of protein. It is also a source of digestible fiber, and hence is a valuable component of ruminant rations, especially for dairy cattle. The potential of alfalfa is, however, much greater, but innovative technological and marketing solutions are needed $[2,3]$ to achieve this potential.

Alfalfa is a plant with a deep tap-root, which contributes to its reliable yield in areas with low or poor seasonal distribution of rainfall. A wide range of tolerance to sowing dates, from early spring to 
late summer, allows sowing when soil moisture conditions are favorable for emergence and initial plant development [4]. Because of progressive decline in forage nutritive value as alfalfa matures, management strategies focus on optimizing nutritive value, yield and persistence. As alfalfa matures, the proportion of stems relative to leaves increases. The highest dry matter (DM) yield of leaves, rich in protein and carotenoids, is achieved at the early developmental stages of alfalfa, and then later a slight decrease is noted due to senescence and leaf loss from the lower, shaded parts of the plant [5]. The digestibility of alfalfa stems decreases markedly with plant development due to the increasing concentration of cell walls and lignin, while the digestibility of leaves changes only slightly as the plant matures. Crude protein concentration in alfalfa leaves is 2 to 3 times greater than in stems, while fiber and lignin concentration in stems is 2 to 3 times greater than in leaves [5]. Moreover, stems have higher concentrations of non-protein and indigestible nitrogen than leaves [6].

The biology of alfalfa suggests that for efficient use of alfalfa biomass, fractionation into leaf and stem components may be justified. Separate harvest of alfalfa leaves and stems creates much broader possibilities for utilization than just as feed for ruminants. For example, the leaves can be used to feed monogastric animals, especially pigs [6-8]. Alfalfa leaves are also used as a dietary supplement and in the treatment of diseases in humans [9]. The stems can be used as feed for heifers, dry cows or other ruminants with low energy requirements [10], or as a raw material for production of bioenergy [11,12], paper, fiberboard or organic fertilizer. In addition, controlled mixing of separated leaves and stems would make it possible to obtain feed products that meet strictly defined nutritional requirements.

It is possible to fractionate both dry and fresh plant material. In dry fractionation, alfalfa is mowed and dried in the field, then cut or baled and further processed in an industrial dryer [13]. Leaves can be separated from dried alfalfa plants using a shaking screen surface [14] or in a horizontal wind tunnel using the different drag coefficients to separate plant fractions [15]. The fractionation of dry plant material, however, is dependent on the weather for initial field drying. A process of simultaneous drying and fractioning freshly cut alfalfa on a specially constructed tumble dryer has been developed to overcome weather uncertainty $[16,17]$. The technology for obtaining high-protein raw material from juice squeezed from cut and macerated alfalfa has also been proposed [18]. With these methods, dependence on the weather is lessened, and raw material losses in the field are minimal, and the opportunities to use the final product are broader. However, the drawbacks are the high costs of equipment, production and transport. Other concepts involve the construction or adaptation of machines that, in field, allow fractionated harvesting by stripping leaves from growing alfalfa stems. Currence and Buchele [19] constructed the first device of this type in the USA. In Sweden, the Fortschritt E303 chopper was adapted for fractionated harvest of alfalfa leaves [20], and in the USA, a harvester designed for green beans [21] was adapted to strip alfalfa leaves. Similar attempts are being made in Germany [22]. Harvested leaves can be preserved by drying or ensiling fresh or wilted material [23-25].

Another practical approach to fractionated harvest is the idea of leaf collection together with upper, immature stem fragments and inflorescences [26] using a modified flail chopper [27]. On a canopy basis stem length has been shown to contribute more to reduction in nutritive value than alfalfa maturity [28], and the lower portions of the stem have greater concentrations of fiber and less crude protein (CP) and lower digestibility than upper stem portions [29,30]. A recent comprehensive review of allometries in plants as drivers of forage nutritive value [31] concludes that leaf loss in the lower canopy, as well as increased lignification of older stem portions are primary factors in reduced nutritive value of the lower canopy of alfalfa. Furthermore, the upper canopy, containing leaves exposed to sunlight and newly developed stem nodes and internodes, represents a highly digestible and high protein portion of the plant. Inflorescences and stem tips account for about $10 \%$ of the alfalfa yield mass, and $\mathrm{CP}$ concentration and in vitro digestibility are intermediate between stems and leaves [32].

The hypothetical assumption is that harvest of leaves and stem tips of alfalfa would result in feed suitable for monogastric animals, and would also allow extending the period of obtaining high-quality feed for ruminants through late flower. This can be of practical importance when weather conditions 
or other organizational considerations do not allow alfalfa to be harvested at earlier development stages when it has the greatest nutritional value. The objective of this study was to assess the yield and nutritive value of alfalfa forage, and residual stubble, harvested at various development stages using a modified flail chopper.

\section{Materials and Methods}

\subsection{Experimental Site and Field Operations}

The field part of the experiment was carried out in 2016 and 2017 at the Mochełek Research Station $\left(53^{\circ} 12^{\prime} \mathrm{N}, 17^{\circ} 51^{\prime} \mathrm{E}\right)$, Poland, in a field of "Ulstar" alfalfa in the second and third production years, with the first and second cuts at various development stages. Harvest dates and alfalfa development stages are presented in Table 1. In 2016, due to an extended period of rainfall, the second cut of alfalfa at the bud stage was not harvested.

Table 1. Alfalfa harvest events over two years.

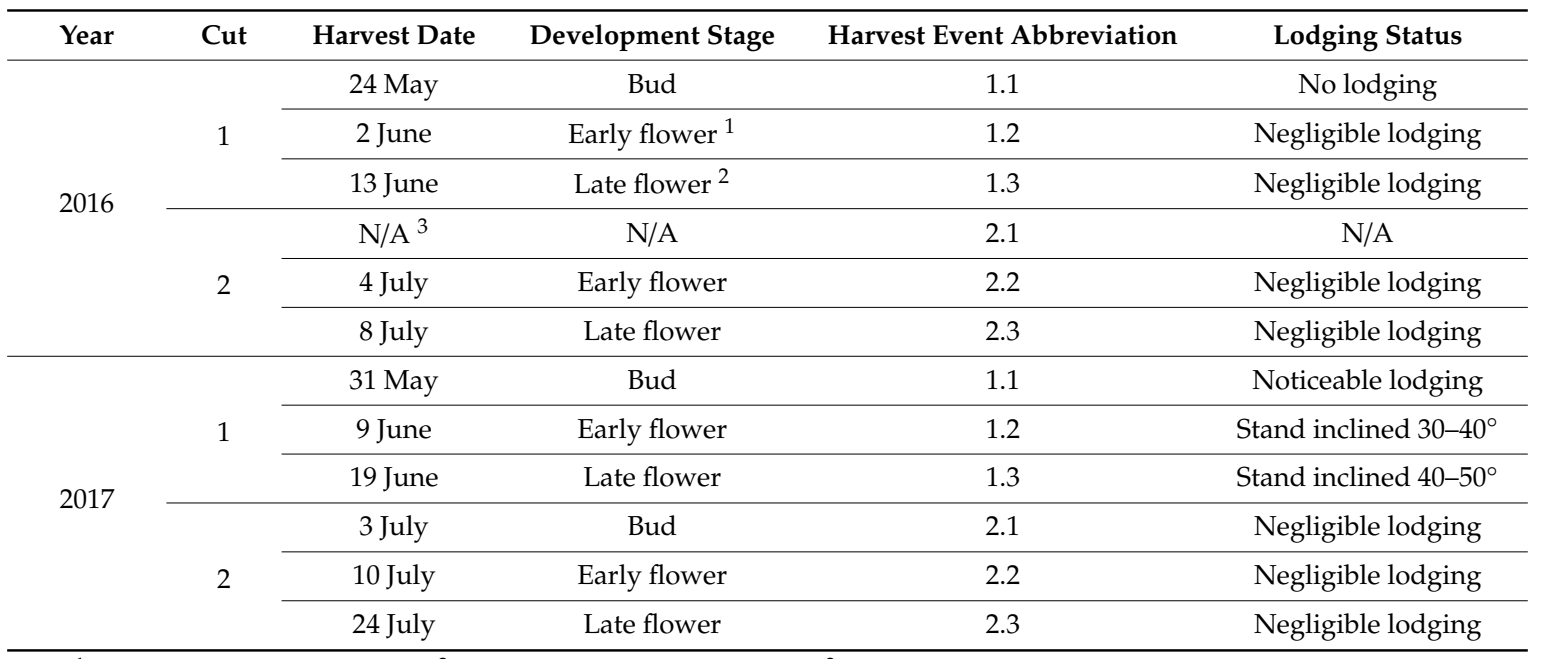

${ }^{1} 10-20 \%$ stems with flowers, ${ }^{2}>80 \%$ stems with flowers and ${ }^{3}$ no harvest taken at bud stage. N/A: not available.

At each harvest event, a $150 \mathrm{~m}^{2}$ portion of the field was designated for sampling. Observations and measurements before each mechanical harvest were made in four representative sites of this area. The height of 10 plants was measured and averaged. A walk-behind sickle-bar mower was used to harvest alfalfa from four $1 \mathrm{~m}^{2}$ microplots leaving a $5 \mathrm{~cm}$ stubble, to represent the mowed (M) treatment. Fresh forage mass was recorded and an approximately $300 \mathrm{~g}$ sample saved for leaf and stem separation. Yield fractions were dried, and after determination of dry matter concentration, were used for laboratory assessment of nutritive value.

The remainder of the $150 \mathrm{~m}^{2}$ area was harvested with a modified flail chopper (MFC). From the whole mass of the yield harvested in this way, four green forage samples of approximately $300 \mathrm{~g}$ each were taken at random, intended for determination of dry matter concentration, leaf and stem proportions and chemical analyses. Values for chemical analysis of separated leaves and stems were mathematically combined, based on proportions, to calculate values for the total harvested biomass. The height of residual stubble and its biomass were measured as described previously for the $\mathrm{M}$ treatment. The yield of green forage harvested using an MFC and its structure were calculated using the results of the measurements of stem residues and fractionated plants from the $\mathrm{M}$ treatment. The plant material was dried at $60{ }^{\circ} \mathrm{C}$ for dry matter determination, and all yield and fractionation results are expressed on a dry matter basis. Each forage harvest with the MFC was preceded by a machine test checking the optimal height setting and working speed. 


\subsection{Technical Characteristics of the Modified Flail Chopper}

The alfalfa was harvested using a modified Orkan 2 flail chopper (UNIA, Grudziadz, Poland). It is a trailed machine, aggregated with a $30-50 \mathrm{hp}$ agricultural tractor, and driven by a power take-off shaft. The original machine is equipped with a flail-type cutting unit with 25 knives arranged on a drum in four rows. It is primarily used for harvesting green grass or legume forage crops, and pneumatic transport of collected material to a trailer attached behind the machine. The working width of the machine is $1.25 \mathrm{~m}$. The drum rotation speed is approximately $1400 \mathrm{rpm}$. The working speed, depending on the crop height and density, is 3 to $4 \mathrm{~km} \mathrm{~h}^{-1}$, and performance 0.3 to $0.4 \mathrm{ha} \mathrm{h}^{-1}$. Other basic technical information about the Orkan 2 flail chopper is provided in the application for a utility model registration [27].

The machine modification [27] consisted of replacing the original knives and supports on the cutting drum of the Orkan 2 machine with 12 five-link pieces of chain arranged on the drum in two opposite rows. In the other two rows, knives were removed from the original supports, leaving $13 \mathrm{knife}$ supports, inverted with the bend in the direction of rotation of the drum. Nominal inside chain link length was $24 \mathrm{~mm}$, with $5 \mathrm{~mm}$ wire diameter. The installed chain sections had the same length as the original knives and fit within the drum cover precisely. A diagram of flail chopper modification is presented in Appendix A. This modification of the main working part of the machine allows stripping the leaves together with fragile stem tips without significant mechanical damage, and pneumatic transport of the crop to the trailer.

\subsection{Chemical Analysis of Plant Material}

Dry subsamples were ground to pass through a $2.0 \mathrm{~mm}$ screen and then reground with a cyclone mill to pass through a $1 \mathrm{~mm}$ screen before nutritive value analysis. Neutral detergent fiber (NDF) and acid detergent fiber (ADF) were analyzed sequentially by the batch procedures outlined by the ANKOM Technology Corporation (Macedon, NY, USA) with an ANKOM 200 fiber analyzer and addition of heat-stable $\alpha$-amylase and sodium sulfite to the neutral detergent solution [33]. A modified Goering and Van Soest [34] procedure was used to determine $48 \mathrm{~h}$ in vitro true digestibility (IVTD) with buffered rumen fluid followed by a neutral detergent wash of post-digestive residues. The rumen fluid incubation was performed with ANKOM F57 filter bags and an ANKOM Daisy II incubator using the batch incubation procedure (ANKOM Technology, Macedon, New York, NY, USA). Neutral detergent fiber digestibility (NDFD) was calculated from NDF and IVTD values as ((NDF - (1000 IVTD)/NDF) $\times 1000$. Total $N$ was determined by the Dumas combustion method with a LECO model FP-528 (LECO Corporation, St. Joseph, MI, USA) and crude protein $(\mathrm{CP})$ was calculated as $\mathrm{N} \times 6.25$.

\subsection{Statistical Analysis}

Plant and stubble height as well as yield and stubble chemical composition data were analyzed using the one-way analysis of variance and yield and chemical composition of alfalfa were analyzed using two-way analysis of variance. The first factor of the experiment was method of harvesting alfalfa: mower (M) or modified flail chopper (MFC); and the second factor was harvest event (cut and development stage of alfalfa): (1.1) first cut-bud, (1.2) first cut, early flower, (1.3) first cut, late flower, (2.1) second cut, bud, (2.2) second cut, early flower and (2.3) second cut, late flower. Significant differences between means were reported using the Tukey LSD test and $p<0.05$. Because of unequal numbers of harvests in the two years, and because of the occurrence of lodging in 2017, years were analyzed separately. Significant harvest method $\times$ harvest event interactions were sometimes observed, and these are noted and addressed in tables and figures. All analyses were carried out using the Statistica 12.1 software package (StatSoft Inc., Tulsa, OK, USA). 


\section{Results and Discussion}

\subsection{Plant Characteristics and Yield Affected by Harvest Method and Timing}

The alfalfa field was in excellent condition with uniform stand density and no significant weed, insect or disease infestations over the period of this research. Alfalfa plants were taller in 2017 than in 2016. In 2017, in the first cut, plants at the flower stage reached a height of $100 \mathrm{~cm}$, which contributed to lodging (Tables 1 and 2). Stubble remaining after harvest with the MFC was, on average, $11 \mathrm{~cm}$ taller in 2016 than in 2017, and $12 \mathrm{~cm}$ taller in the first cut than second cut in 2016 (Table 2). The stems remaining in the field accounted for, on average, 52\% of the total plant height in 2016, and 35\% in 2017. In both years, the plants harvested in the first cut at greater development stages left progressively taller stubble. In the second cut, no such relationship was found.

Approximately $60 \%$ of the potential DM yield of alfalfa was harvested with the MFC in 2016 and about $74 \%$ in 2017 (Table 2), leaving 40\% and 26\% of the crop mass, respectively, in the field as stubble. Shinners et al. [21] reported that after harvesting leaves with a leaf stripper, the stubble remaining in the field accounted for $44 \%$ of the total DM mass of alfalfa. Harvest method affected DM yield at each harvest, and to a much greater extent in the first cut than the second cut. In the first cut, difference due to harvest method, averaged over plant development stage, was $267 \mathrm{~g} \mathrm{~m}^{-2}$ in the first year and $146 \mathrm{~g} \mathrm{~m}^{-2} \mathrm{DM}$ in the second year, and in the second cut only 95 and $84 \mathrm{~g} \mathrm{~m}^{-2}$, respectively. This relationship is closely related to the height of the residual stubble. The proportion of leaves in the harvested forage biomass tended to decrease as the crop matured with both harvest methods, but leaf proportion was $22 \%$ greater in forage harvested with the MFC than with the mower.

Previous research has shown that a flail chopper, modified similarly to the one used in the current research, can successfully harvest lodged alfalfa [19]. In the MFC used for harvesting, the height of the stubble can be adjusted by changing the tractor ground speed, and to a smaller extent by adjusting the machine working height. The height of the stubble left, especially in the first cut, was positively correlated with the dry matter concentration and the concentration of both fiber fractions (unpublished data), i.e., traits associated with the developmental stage of alfalfa. In the MFC version used, harvest of residual stubble required an additional pass of the tractor with a mower. However, it is possible to further modify the MFC to allow harvest of stubble at the same time. Similar to the report by Sikora et al. [25], rapid drying of stubble, both standing and mown, was observed. This was associated with abrasion of stems by the MFC. Currence and Buchele [19] and Shinners et al. [21] report that 7 to 14 days after harvest, leaves regrow from undamaged portions of stems left after strip harvest. However, these leaves were smaller compared to normal regrowth of alfalfa leaves. Leaf regrowth on stubble was not monitored in the current research. 
Table 2. Plant and stubble height and dry matter yield and leaf proportion in alfalfa at two cuts and three maturities, dependent on harvest method.

\begin{tabular}{|c|c|c|c|c|c|c|c|c|c|}
\hline Characteristic & Year & Harvest Method ${ }^{1}$ & Bud & $\begin{array}{c}\text { 1st Cut } \\
\text { Early Flower }\end{array}$ & Late Flower & Bud & $\begin{array}{c}\text { 2nd Cut } \\
\text { Early Flower }\end{array}$ & Late Flower & Mean \\
\hline \multirow{2}{*}{ Plant height $(\mathrm{cm})$} & 2016 & \multirow{2}{*}{$\mathrm{M}$ and MFC } & $70 \mathrm{~b}$ & $86 a^{2}$ & $90 \mathrm{a}$ & - & $65 \mathrm{~b}$ & $71 \mathrm{~b}$ & 76 \\
\hline & 2017 & & $87 \mathrm{ab}$ & $100 \mathrm{a}$ & $102 \mathrm{a}$ & $58 \mathrm{c}$ & $70 \mathrm{c}$ & $85 \mathrm{~b}$ & 83 \\
\hline \multirow{2}{*}{ Stubble height $(\mathrm{cm})$} & 2016 & \multirow{2}{*}{ MFC } & $34 \mathrm{~b}$ & $48 \mathrm{a}$ & $51 \mathrm{a}$ & - & $31 \mathrm{~b}$ & $34 \mathrm{~b}$ & 40 \\
\hline & 2017 & & $26 \mathrm{bc}$ & $29 \mathrm{~b}$ & $41 \mathrm{a}$ & $20 \mathrm{c}$ & $29 \mathrm{~b}$ & $27 \mathrm{bc}$ & 29 \\
\hline \multirow{4}{*}{ Dry matter yield $\left(\mathrm{g} \mathrm{m}^{-2}\right)$} & \multirow{2}{*}{2016} & $\mathrm{M}$ & $567 \mathrm{~b}$ & $558 \mathrm{~b}$ & $638 \mathrm{a}$ & - & $314 \mathrm{c}$ & $364 \mathrm{c}$ & $488 \mathrm{~A}^{3}$ \\
\hline & & MFC & $277 \mathrm{bc}$ & $319 \mathrm{ab}$ & 366 a & - & $217 c$ & $272 \mathrm{bc}$ & $290 \mathrm{~B}$ \\
\hline & \multirow{2}{*}{2017} & $\mathrm{M}$ & $493 \mathrm{~b}$ & $510 \mathrm{~b}$ & $662 \mathrm{a}$ & $260 \mathrm{~d}$ & $312 \mathrm{~d}$ & $402 \mathrm{c}$ & $440 \mathrm{~A}$ \\
\hline & & MFC & $318 \mathrm{c}$ & $408 \mathrm{~b}$ & $501 \mathrm{a}$ & $173 \mathrm{~d}$ & $230 \mathrm{~d}$ & $318 \mathrm{c}$ & $324 \mathrm{~B}$ \\
\hline \multirow{4}{*}{ Leaf proportion in yield DM (\%) } & \multirow{2}{*}{2016} & M & $46 \mathrm{ab}$ & $38 \mathrm{~b}$ & $36 \mathrm{~b}$ & - & $52 \mathrm{a}$ & $48 \mathrm{a}$ & $44 \mathrm{~B}$ \\
\hline & & MFC & $82 \mathrm{a}$ & $68 \mathrm{bc}$ & $63 c$ & - & $76 \mathrm{ab}$ & $64 \mathrm{c}$ & $70 \mathrm{~A}$ \\
\hline & \multirow{2}{*}{2017} & $\mathrm{M}$ & $36 \mathrm{bc}$ & $33 c$ & $37 \mathrm{bc}$ & $50 \mathrm{a}$ & 47 a & $44 \mathrm{ab}$ & $41 \mathrm{~B}$ \\
\hline & & MFC & $56 c$ & $41 \mathrm{~d}$ & $50 \mathrm{c}$ & $76 \mathrm{a}$ & $64 \mathrm{~b}$ & $56 c$ & $57 \mathrm{~A}$ \\
\hline
\end{tabular}

${ }^{1}$ Sickle-bar mower (M), modified flail chopper (MFC) ${ }^{2}$ means within rows followed by different lowercase letters are significantly different at the $95 \%$ confidence level ${ }^{3}$ means within columns followed by different uppercase letters are significantly different at the $95 \%$ confidence level. 


\subsection{Nutritive Value Affected by Harvest Method and Timing}

In alfalfa from all harvests in both years, $\mathrm{CP}$ concentration was significantly greater in alfalfa harvested with an MFC than harvested with a mower, on average by $28 \mathrm{~g} \mathrm{~kg}^{-1} \mathrm{DM}$ (Figure 1A,B). For various harvests, these differences ranged from 13 to $40 \mathrm{~g} \mathrm{~kg}^{-1} \mathrm{DM}$. At similar maturity stages, $\mathrm{CP}$ concentrations were greater in second than first cut alfalfa. The CP concentrations in the MFC harvest, which was a mixture of leaves and stem tips, was slightly lower than reported by Albrecht et al. [5] and Lamb et al. [35] for cleanly separated leaves.
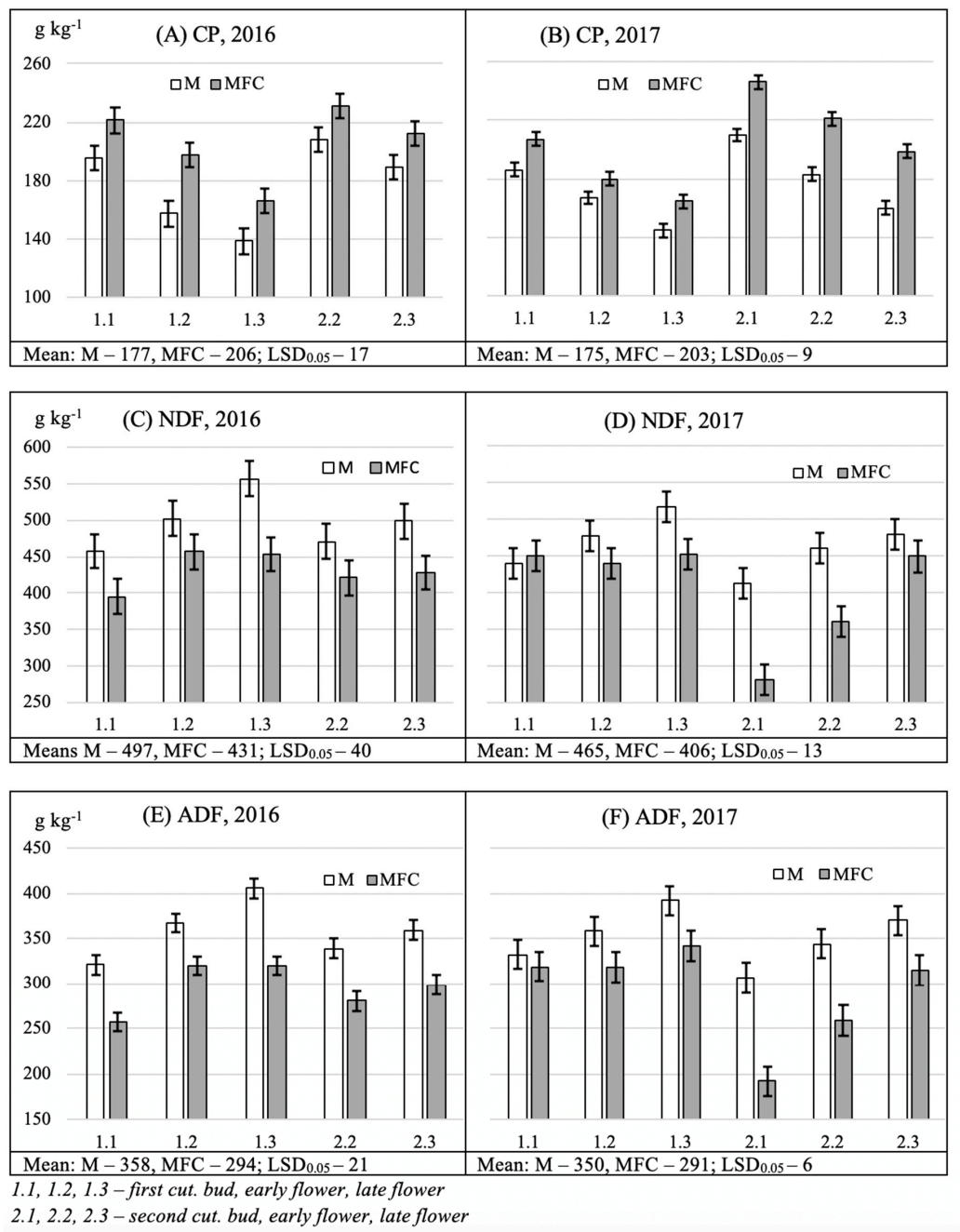

Figure 1. (A,B) Crude protein (CP), (C,D) neutral deteegent fiber (NDF), (E,F) acid detergent fiber (ADF) concentration of alfalfa harvested whith a sickle-bar mower (M) or modified flail chopper (MFC) dependent on cut and plant development stage. The bars indicate $\operatorname{LSD}(p=0.05)$ values for comparing means across harvest methods and events $(\mathbf{A}, \mathbf{B}, \mathbf{E})$ or between harvest methods within harvest event $(\mathbf{C}, \mathbf{D}, \mathbf{F})$ where harvest method $\mathrm{X}$ harvest event interaction was detected.

The NDF concentration of alfalfa harvested using an MFC was $66 \mathrm{~g} \mathrm{~kg}^{-1}$ DM lower than alfalfa harvested with a mower in 2016, and $59 \mathrm{~g} \mathrm{~kg}^{-1}$ DM lower in 2017 (Figure 1C,D). A significant effect of harvest method on NDF concentration was not observed in 1.2 alfalfa in 2016, or in 1.1 alfalfa in 2017.

Acid detergent fiber concentration of alfalfa harvested with an MFC was $64 \mathrm{~g} \mathrm{~kg}^{-1} \mathrm{DM}$ lower than when harvested with a mower in 2016, and $60 \mathrm{~g} \mathrm{~kg}^{-1}$ DM lower in 2017 (Figure 1E,F). In 2016, ADF concentration was significantly lower in alfalfa at each harvest event when harvested with the MCF compared to the mower. Similar results were observed in 2017, except that harvest method had no effect on ADF concentration in 1.1 alfalfa. 
The IVTD of alfalfa harvested using the MFC was significantly greater at most harvest events, with exceptions of 1.2 in 2016 and 1.1 in 2017, compared to alfalfa harvested using a mower (Figure 2A,B). On average, the difference in favor of the MFC harvest method was $50 \mathrm{~g} \mathrm{~kg}^{-1}$ in 2016 and $56 \mathrm{~g} \mathrm{~kg}^{-1}$ in 2017. In the first year of the study, no effect of harvest method on NDFD concentration was found. In 2017, when harvest was carried out with an MFC, NDFD concentration in alfalfa was, on average, $72 \mathrm{~g} \mathrm{~kg}^{-1} \mathrm{NDF}$ greater compared to alfalfa harvested with a mower (Figure 2C,D).

Ash concentration in alfalfa forage harvested with the MFC was, on average, 15\% greater in 2016 and $10 \%$ greater in 2017 than alfalfa harvested with a mower (Figure 2E,F). However, this relationship did not apply to all harvest events, with no significant differences in ash concentrations between harvest methods in 1.1 and 2.3 harvests in 2016 and 1.2 and 1.3 harvests in 2017. The difference in ash concentration between the two harvest methods ranged from $28 \mathrm{~g} \mathrm{~kg}^{-1}$ in $1.3,2016$, to no difference in $1.2,2017$. The suction associated with flail harvesters is known to carry soil with the forage, and soil moisture and texture have been demonstrated as factors in soil contamination with flail harvesters [36]. The concentration of ash associated with either harvest system is in the lower end of the range typically reported for alfalfa hay [37].
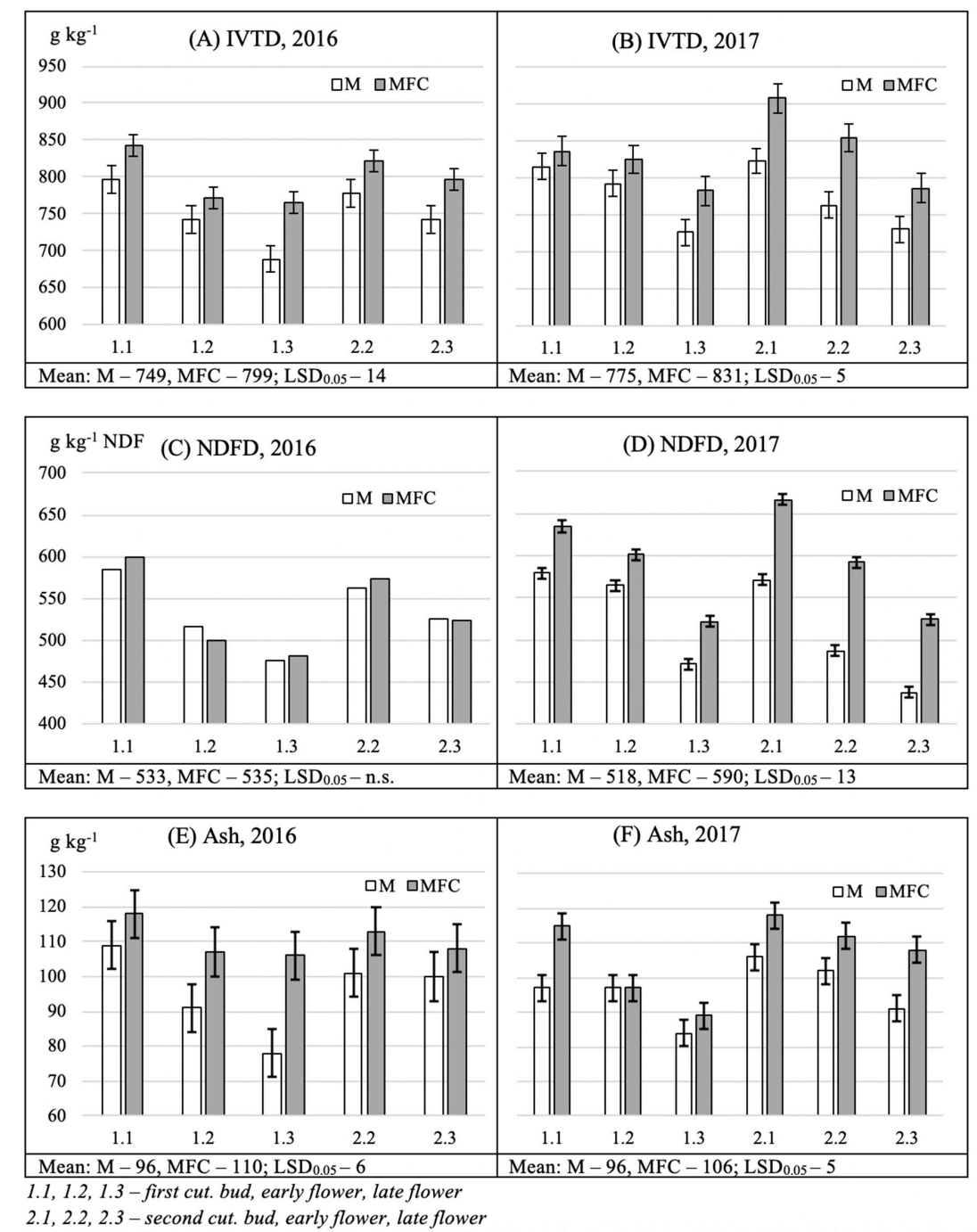

Figure 2. (A,B) in vitro true digestibility (IVTD), (C,D) neutral detergent fiber digestibility (NDFD) and $(\mathrm{E}, \mathrm{F})$ ash concentration of alfalfa harvested with a sickle-bar mower $(\mathrm{M})$ or modified flail chopper (MFC) dependent on cut and plant development stage. The bars indicate LSD $(p=0.05)$ values for comparing means across harvest methods and event (D) or between harvest methods within harvest event $(\mathbf{A}, \mathbf{B}, \mathbf{E}, \mathbf{F})$ where harvest method $\mathbf{X}$ harvest event interaction was detected. 
Regarding $\mathrm{CP}$ concentration and both fiber fractions, the following relationships were found regardless of cut and year of the study: in alfalfa harvested with the MFC at the early flower stage, $\mathrm{CP}$ concentration was at a similar or higher level, and NDF and ADF at a similar or lower level compared to forage harvested with a mower at the bud stage. The same relationship occurred with more mature forage. In alfalfa harvested with the MFC at late flower, CP concentration was at a similar or higher level, and NDF and ADF at a similar or lower level as in forage harvested with a mower at early flower. The trend for IVTD was similar to that for CP concentration, with the only exception for harvests 1.1 and 1.2 in 2016.

The observed relationships indicate the possibility of delaying harvest without substantial loss in feed value if weather conditions do not allow alfalfa harvest at bud or early flower. The MFC can also be a useful machine for harvesting alfalfa intended for direct feeding of dairy cattle, which in Central Europe allows delaying harvest by 7 to 10 days. Harvested plant material, if not fed directly, cannot remain in the field, but must be dried in an industrial dryer or ensiled, as proposed for separated leaves in previous research $[20,21,23,25]$.

In many cases, the height of stubble remaining in the field after MFC harvest was about $30 \mathrm{~cm}$. This prompted comparison of nutritive value parameters of alfalfa mowed with the MCF or a sickle-bar mower at a height of $30 \mathrm{~cm}$ above the soil surface. Such an analysis was carried out in 2017 with second cut, late flower alfalfa, and it did not reveal significant differences for any nutritive value parameter resulting from harvest method (data not shown). This suggests the need to make some structural adjustments so that the stems remaining in the field have a greater height. A review recently published by Lemaire and Bélanger [31] describes the upper canopy as having a fairly consistent and high nutritive value, whereas the lower canopy is variable because of leaf loss and changing chemistry of stems as they mature. These relationships could be useful in further modification of the flail harvester, or refining its use in the field, for example, adjusting operating height or ground speed, to more precisely harvest the desired canopy fraction. Consideration of time since last harvest as well as current canopy height could also help in targeting the appropriate portion of the canopy for specific uses.

The choice of alfalfa cultivars with stiffer, more upright stems may be justified for harvest with an MFC. Alfalfa germplasms from southern Europe, referred to as Flemish types, are a genetic source for larger, stiffer stems thought to improve lodging resistance [38]. Cultivars with Flemish characteristics may be better suited to leaf removal with the MFC. Differences in the chemical composition of stems within the species M. sativa L. are relatively small [39], so differences in nutritional characteristics of residual stubble would not be expected among cultivars.

Due to the relatively high concentration of both fiber fractions, the assumption that alfalfa collected with an MFC will be suitable feed for monogastric livestock was not confirmed. However, forage harvested with an MFC at bud or early flower stages meets the criteria of a fiber enrichment additive for sows [40,41], as well as a protein supplement. The proposed harvest method also creates an opportunity to delay harvest and reduce the number of cuts during the growing season, and thereby extend the life of the alfalfa stand.

\subsection{Qualitative Characteristics of Stubble Remaining after Harvest with an MFC}

The chemical composition of stubble remaining after harvesting alfalfa with the MFC changed slightly as maturity advanced (Table 3). Crude protein concentration decreased with advancing development, both in the first and second cut. There was a tendency for NDF and ADF concentrations in residual stubble to increase with maturity at harvest, but this was not always statistically significant. Likewise, IVTD tended to decrease slightly from the bud stage through late flower stage, but differences between maturity stages were not always statistically significant. The ash concentration ranged from 68 to $96 \mathrm{~g} \mathrm{~kg}^{-1}$, and in both cuts, there was a tendency for decreasing ash concentration as plant development progressed. 
Table 3. Crude protein (CP), neutral detergent fiber (NDF), acid detergent fiber (ADF), in vitro true digestibility (IVTD and ash concentrations in residual stubble after alfalfa was harvested with a modified flail chopper.

\begin{tabular}{|c|c|c|c|c|c|c|c|c|c|}
\hline \multirow{2}{*}{ Characteristic } & \multirow{2}{*}{ Year } & \multicolumn{3}{|c|}{ 1st Cut } & \multicolumn{3}{|c|}{ 2nd Cut } & \multirow{2}{*}{ Mean } & \multirow{2}{*}{$\operatorname{LSD}(p<0.05)$} \\
\hline & & Bud & Early Flower & Late Flower & Bud & Early Flower & Late Flower & & \\
\hline \multirow{2}{*}{$\mathrm{CP}, \mathrm{g} \mathrm{kg}^{-1}$} & 2016 & $130 \mathrm{a}^{1}$ & $104 \mathrm{~b}$ & $104 \mathrm{~b}$ & - & $122 \mathrm{ab}$ & $106 \mathrm{~b}$ & 111 & 21 \\
\hline & 2017 & $131 \mathrm{a}$ & $125 \mathrm{a}$ & $98 \mathrm{~b}$ & $124 \mathrm{a}$ & $113 \mathrm{a}$ & $82 \mathrm{~b}$ & 112 & 23 \\
\hline \multirow{2}{*}{$\mathrm{NDF}, \mathrm{g} \mathrm{kg}^{-1}$} & 2016 & $552 \mathrm{~b}$ & $623 \mathrm{a}$ & $644 \mathrm{a}$ & - & $636 \mathrm{a}$ & $656 a$ & 622 & 57 \\
\hline & 2017 & $564 \mathrm{~b}$ & $565 \mathrm{~b}$ & $583 \mathrm{~b}$ & $569 \mathrm{~b}$ & $591 \mathrm{~b}$ & $660 \mathrm{a}$ & 589 & 53 \\
\hline \multirow{2}{*}{$\mathrm{ADF}, \mathrm{g} \mathrm{kg}^{-1}$} & 2016 & $410 \mathrm{~b}$ & $466 \mathrm{a}$ & $485 \mathrm{a}$ & - & $470 \mathrm{a}$ & $492 \mathrm{a}$ & 466 & 45 \\
\hline & 2017 & $424 \mathrm{~b}$ & $426 \mathrm{~b}$ & $448 \mathrm{~b}$ & $441 \mathrm{~b}$ & $456 \mathrm{~b}$ & 517 a & 452 & 46 \\
\hline \multirow{2}{*}{ IVTD, $\mathrm{g} \mathrm{kg}^{-1}$} & 2016 & 707 a & $637 \mathrm{~b}$ & $633 \mathrm{~b}$ & - & $607 \mathrm{~b}$ & $587 \mathrm{~b}$ & 634 & 14 \\
\hline & 2017 & $705 \mathrm{a}$ & $691 \mathrm{a}$ & $683 \mathrm{a}$ & $694 \mathrm{a}$ & $664 \mathrm{a}$ & $571 \mathrm{~b}$ & 668 & 46 \\
\hline \multirow{2}{*}{ Ash $\mathrm{g} \mathrm{kg}^{-1}$} & 2016 & $96 \mathrm{a}$ & $85 \mathrm{ab}$ & $77 \mathrm{ab}$ & - & $71 \mathrm{~b}$ & $72 \mathrm{~b}$ & 80 & 14 \\
\hline & 2017 & $88 \mathrm{a}$ & $90 \mathrm{a}$ & $75 \mathrm{~b}$ & $93 \mathrm{a}$ & $83 a$ & $68 \mathrm{~b}$ & 83 & 13 \\
\hline
\end{tabular}

${ }^{1}$ Means within rows followed by different lowercase letters are significantly different at the $95 \%$ confidence level. 
In our study, $\mathrm{CP}$ concentration in the stems remaining in the field was on average $20 \mathrm{~g} \mathrm{~kg}^{-1} \mathrm{DM}$ lower, and the NDF concentration was $50 \mathrm{~g} \mathrm{~kg}^{-1} \mathrm{DM}$ greater than that reported by Shinners et al. [21], where the concentration of these components in remaining stems was assessed after the leaves were stripped off. Our goal was to harvest the higher quality upper stems [31] with the leaf fraction, reducing nutritive value of biomass left behind in the residual stubble. The concentration of ADF in the stems of both experiments, however, was similar. In general, the chemical composition of stem stubble remaining in the field indicates that it can be used as feed for classes of ruminants with low nutritional demand, such as dairy heifers or dry cows. Su et al. [10] showed that alfalfa stemlage, similar to wheat straw, can be used to dilute high nutrient density forages, such as corn (Zea mays L.) or high-quality alfalfa silage, for dairy heifers.

In addition to livestock feed, residual stems may have other uses. They could provide mulch formed from fragments of alfalfa stems cut and left in the field. Benefits expected are reduced weeds, reduced soil water loss, improved winter survival by insulating crowns, and multiplying beneficial microorganisms. The prospect of using stem residues for soil mulching, as well as the values described above, indicate the special usefulness of an MCF on organic farms [42]. Alfalfa stems, after leaf removal, have also been investigated as a source of bioenergy [35].

\section{Conclusions}

In the two-year field study, the feasibility of fractionated alfalfa harvest with an MFC and the feed value of the harvested fraction and residual stubble, at development stages from bud to late flower, was investigated. The quantitative and qualitative effects of this harvest method that fractionates yield components were compared with alfalfa harvested in parallel with a mower. An MFC enables precision harvesting of most leaves and upper parts of alfalfa plants, including inflorescences, with simultaneous pneumatic transport of these parts of the yield to a trailer attached behind the machine. The mass of the yield fraction harvested with the MFC, its structure and forage nutritive value were affected by cut and plant development stage, and nutritive value was consistently greater than alfalfa harvested with a mower. The stubble remaining in the field maintained moderate feed value regardless of the development stage. Harvest with an MFC allows delaying harvest to late flowering stage while maintaining reasonably high nutritive value in the harvested forage. Further refinement of the MFC will be necessary to more precisely harvest the leaf fraction for use as a protein supplement in non-ruminant livestock rations. The seemingly perpetual deficit of homegrown protein for livestock rations in Europe has driven the quest for alternative protein sources, and an environmentally friendly crop such as alfalfa is an ideal candidate if strategies to efficiently separate protein rich leaves are developed.

Author Contributions: Conception and design of the research, S.I. and J.A.; Data acquisition, S.I., J.A., and K.A.A.; Data analysis, S.I.; Writing—original draft, J.A.; Writing—review and editing, K.A.A., J.A., S.I. All authors have read and agreed to the published version of the manuscript.

Funding: Research supported by Poland's Ministry of Science and Higher Education as part of the statutory activities of the Department of Agronomy, University of Science and Technology in Bydgoszcz: 2016-2017.

Conflicts of Interest: The authors declare no conflict of interest. 


\section{Appendix A}

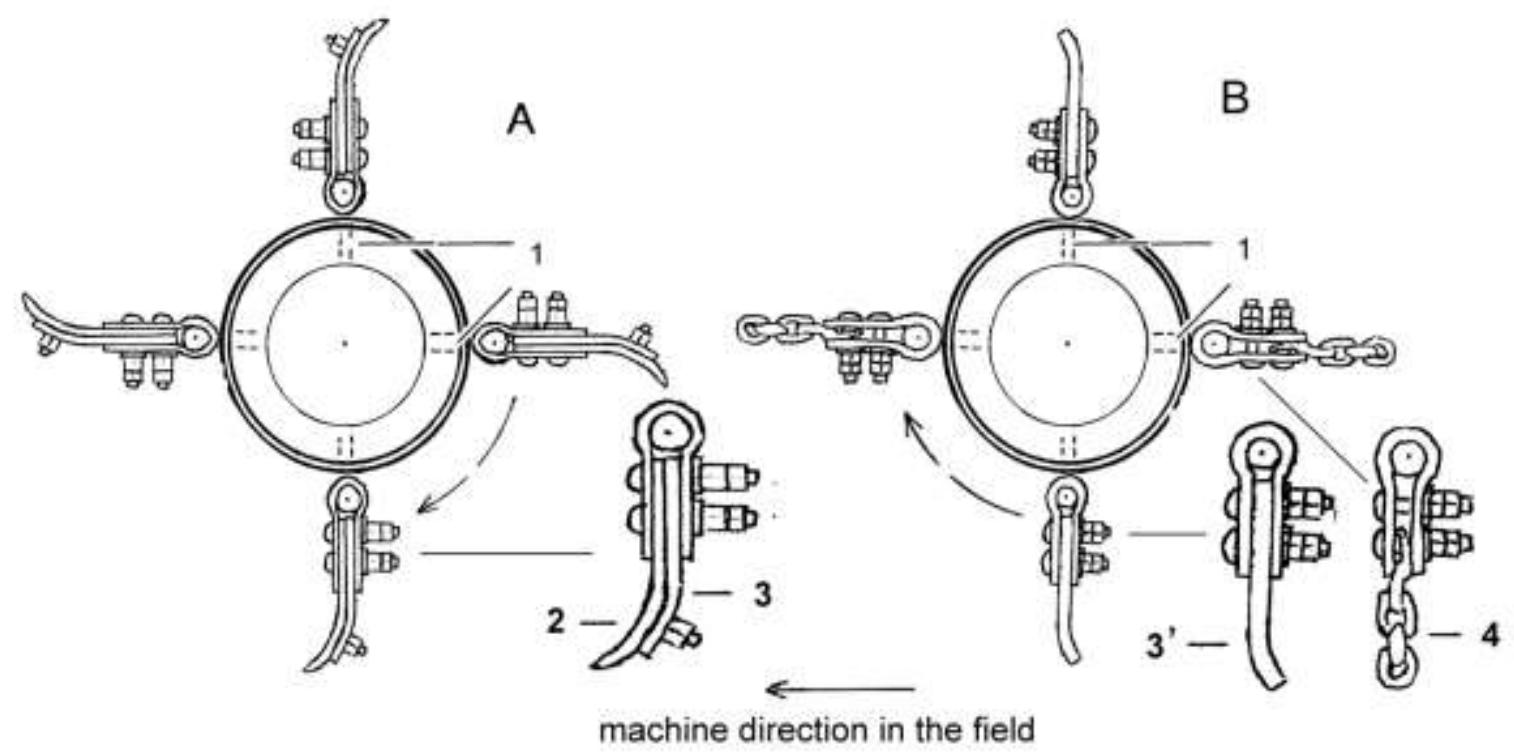

Figure A1. Diagram of modifications to flail chopper drum-original (A) and modified (B); (1) rows with knives, (2) knife, (3) support, (3') inverted support and (4) chain.

\section{References}

1. Report from the Commission to the Council and the European Parliament on the Development of Plant Proteins in the European Union (2018) COM/2018/757 Final. 2018. Available online: https://ec.europa.eu/info/sites/info/files/food-farming-fisheries/plants_and_plant_products/documents/ report-plant-proteins-com2018-757-final_en.pdf (accessed on 12 March 2020).

2. de Visser, C.L.M.; Schreuder, R.; Stoddard, F. The EU's dependency on soya bean import for the animal feed industry and potential for EU produced alternatives. OCL 2014, 21, D407. [CrossRef]

3. Mielmann, A. The utilization of lucerne (Medicago sativa): A review. Br. Food J. 2013, 115, 590-600. [CrossRef]

4. Andrzejewska, J.; Albrecht, K.A.; Ignaczak, S.; Skinder, Z. Method and time of alfalfa sowing when climate is changing. Acta Sci. Pol. Agric. 2015, 14, 3-13.

5. Albrecht, K.A.; Wedin, W.F.; Buxton, D.R. Cell-wall composition and digestibility of alfalfa stems and leaves. Crop Sci. 1987, 27, 735-741. [CrossRef]

6. Hakl, J.; Dostälové, A.; Sklenéf, J.; Klejzar, T. Evaluation of potential of forage legume leaves as a protein source for organic pig farms. Grassl. Sci. Eur. 2018, 23, 215-217.

7. Bilanski, W.K. Enhanced utilization of forage plants through fractionation-state of the art. Int. Agric. Eng. J. 1992, 1, 1-13.

8. Malmlöf, K.; Hellberg, S.; Cortova, Z.; Jansson, L. Lucerne in Pig Feeding. 1. Nutritive Value of Whole and Fractionated Lucerne Meal; Report No. 196; Swedish University of Agricultural Sciences, Department of Animal Nutrition and Management: Uppsala, Sweden, 1990; pp. 1.1-1.6.

9. Bora, K.S.; Sharma, S. Phytochemical and pharmacological potential of Medicago sativa: A review. Pharm. Biol. 2011, 49, 211-220. [CrossRef]

10. Su, H.; Akins, M.S.; Esser, N.M.; Ogden, R.; Coblentz, W.K.; Kalscheur, K.F.; Hatfield, R. Effects of feeding alfalfa stemlage or wheat straw for dietary energy dilution on nutrient intake and digestibility, growth performance, and feeding behavior of Holstein dairy heifers. J. Dairy Sci. 2017, 100, 7106-7115. [CrossRef]

11. Hakl, J.; Mášková, K.; Fuksa, P.; Šantrůček, J. The changes in gross energy concentration in lucerne leaves and stems in the first cut. In Proceedings of the 14th International Symposium Forage Conservation, Brno, Czech Republic, 17-19 March 2010; pp. 130-132. 
12. Slepetiene, A.; Slepetys, J.; Tilvikiene, V.; Amaleviciute, K.; Liaudanskiene, I.; Ceseviciene, J.; Kadziuliene, Z.; Dabkevicius, Z.; Buliauskaite, R. Evaluation of chemical composition and biogas production from legumes and perennial grasses in anaerobic digestion using the oxitop system. Fresenius Environ. Bull 2016, 25, 1342-1347.

13. Adapa, P.K.; Schoenau, G.J.; Tabil, L.G.; Sokhansanj, S.; Crerar, B. Pelleting of fractionated alfalfa products. In Proceedings of the ASAE Annual Meeting, St. Joseph, MI, USA, 27-30 July 2003; Paper No. 036069.

14. Chrisman, J.; Kohler, G.O.; Mottola, A.C.; Nelson, J.W. High and Low Protein Fractions by Separation Milling of Alfalfa; Agricultural Research Services: Washington, DC, USA, 1971.

15. Bilanski, W.K.; Graham, W.D.; Mowat, D.N.; Mkomwa, S.S. Separation of alfalfa silage into stem and leaf fractions in a horizontal air stream. Trans. ASAE 1989, 32, 1684-1690. [CrossRef]

16. Arinze, E.A.; Schoenau, G.J.; Sokhansanj, S.; Adapa, P. Aerodynamic separation and fractional drying of alfalfa leaves and stems-A review \& new concept. Dry. Technol. 2003, 21, 1673-1702.

17. Adapa, P.K.; Schoenau, G.J.; Arinze, E.A. Fractionation of alfalfa into leaves and stems using a three-pass rotary drum dryer. Biosyst. Eng. 2004, 91, 455-463. [CrossRef]

18. Koegel, R.G.; Straub, R.J.; Shinners, K.J.; Broderick, G.A.; Mertens, D.R. An overview of physical treatments of lucerne performed at Madison, Wisconsin, for improving properties. J. Agric. Eng. Res. 1992, 52, $183-191$. [CrossRef]

19. Currence, H.D.; Buchele, W.F. Leaf-strip harvester for alfalfa. Agric. Eng. 1967, 48, $20-23$.

20. Grajewski, J.; Malmlöf, K.; Böhm, J. New technology of harvest and preservation of lucerne leaves. Biul. Nauk. Przem. Pasz. 1994, 23, 30-36.

21. Shinners, K.J.; Herzmann, M.E.; Binversie, B.N.; Digman, M.F. Harvest fractionation of alfalfa. Trans. ASABE 2007, 50, 713-718. [CrossRef]

22. Liebhardt, P.; Maxa, J.; Bernhardt, H.; Thurner, S. Harvesting techniques for legumes (especially leaves) as protein feed for monogastric animals. Grassl. Sci. Eur. 2019, 24, 69-71.

23. Digman, M.F.; Runge, T.M.; Shinners, K.J.; Hatfield, R.D. Wet fractionation for improved utilization of alfalfa leaves. Biol. Eng. Trans. 2013, 6, 29-42. [CrossRef]

24. Malmlöf, K.; Hellberg, S.; Grajewski, J.; Cortova, Z. Lucerne in Pig Feeding. 2. Nutritive Value of Dried and Ensiled Lucerne Leaves in Growing Pigs; Report No. 196; Swedish University of Agricultural Sciences, Department of Animal Nutrition and Management: Uppsala, Sweden, 1990; pp. 2:1-2:8.

25. Sikora, M.C.; Hatfield, R.D.; Kalscheur, K.F. Fermentation and chemical composition of high-moisture lucerne leaf and stem silages harvested at different stages of development using a leaf stripper. Grass Forage Sci. 2019, 74, 254-263. [CrossRef]

26. Andrzejewska, J.; Ignaczak, S.; Albrecht, K.A.; Surucu, M. Fractional harvest of perennial legumes can improve forage quality and their exploitation. Grassl. Sci. Eur. 2017, 22, 509-511.

27. Ignaczak, S.; Andrzejewska, J. Green Forage Cutter for Leaf Harvest; The Patent Office of the Republic of Poland: Warsaw, Poland, 2016; p. 125066.

28. Hintz, R.W.; Albrecht, K.A. Prediction of alfalfa chemical composition from maturity and plant morphology. Crop Sci. 1991, 31, 1561-1565. [CrossRef]

29. Buxton, D.R.; Hornstein, J.S.; Wedin, W.F.; Marten, G.C. Forage quality in stratified canopies of alfalfa, birdsfoot trefoil, and red clover. Crop Sci. 1985, 25, 273-279. [CrossRef]

30. Parsons, D.; Cherney, D.J.; Peterson, P.R. Preharvest neutral detergent fiber concentration of alfalfa as influenced by stubble height. Agron. J. 2009, 101, 769-774. [CrossRef]

31. Lemaire, G.; Bélanger, G. Allometries in plants as drivers of forage nutritive value: A review. Agriculture 2020, 10, 5. [CrossRef]

32. Fick, G.W.; Holthausen, R.S. Significance of parts other than blades and stems in leaf-stem separations of alfalfa herbage. Crop Sci. 1975, 15, 259-262. [CrossRef]

33. Hintz, R.W.; Mertens, D.R.; Albrecht, K.A. Effects of sodium sulfite on recovery and composition of detergent fiber and lignin. J. AOAC Int. 1996, 79, 16-22. [CrossRef]

34. Goering, H.K.; Van Soest, P.J. Forage fiber analyses: Apparatus, reagents, procedures, and some applications. In USDA Agricultural Handbook; Government Printing Office: Washington, DC, USA, 1970; p. 379.

35. Lamb, J.F.S.; Jung, H.-J.G.; Sheaffer, C.C.; Samac, D.A. Alfalfa leaf protein and stem cell wall polysaccharide yields under hay and biomass management systems. Crop. Sci. 2007, 47, 1407-1415. [CrossRef] 
36. Stringer, W.C.; Peiffer, R.A. Soil contamination of forage samples by forage plot harvesters. Agron. J. 1981, 73, 65-66. [CrossRef]

37. Neu, A.E.; Sheaffer, C.C.; Undersander, D.J.; Hall, M.H.; Kniffen, D.M.; Wells, M.S.; Catalano, D.N.; Martinson, K.L. Hay rake-type effect on ash and forage nutritive values of alfalfa hay. Agron. J. 2017, 109, 2163-2171. [CrossRef]

38. Barnes, D.K.; Bingham, E.T.; Murphy, R.P.; Hunt, O.J.; Beard, D.F.; Skrdla, W.H.; Teuber, L.R. Alfalfa Germplasm in the United States: Genetic Vulnerability, Use, Improvement, and Maintenance; United States Department of Agriculture, Agricultural Research Service: Washington, DC, USA, 1977.

39. Milić, D.; Karagić, D.; Vasiljević, S.; Mikić, A.; Mijić, B.; Katić, S. Leaf and stem chemical composition of divergent alfalfa cultivars. Biotech. Anim. Husb. 2011, 27, 1505-1511. [CrossRef]

40. Edwards, L.E.; Plush, K.J.; Ralph, C.R.; Morrison, R.S.; Acharya, R.Y.; Doyle, R.E. Enrichment with lucerne hay improves sow maternal behaviour and improves piglet survival. Animals 2019, 9, 558. [CrossRef] [PubMed]

41. Péter, P.; Anikó, H.; János, G.; György, F.S. Effect of chopped alfalfa hay supplementation of the feedstuffs during pregnancy on breeding sows' reproductive performance. Magyar Állatorvosok Lapja 2008, 130, $199-204$.

42. Rehman, M.; Liu, J.; Johnson, A.C.; Dada, T.E.; Gurr, G.M. Organic mulches reduce crop attack by sweet potato weevil (Cylas formicarius). Sci. Rep. 2019, 9, 14860. [CrossRef] [PubMed]

(C) 2020 by the authors. Licensee MDPI, Basel, Switzerland. This article is an open access article distributed under the terms and conditions of the Creative Commons Attribution (CC BY) license (http://creativecommons.org/licenses/by/4.0/). 